\title{
Materials' physics and chemistry for space application: in memoriam of Christopher Semprimoschnig
}

\author{
Ugo Lafont ${ }^{1} \cdot$ Adrian Tighe $^{1} \cdot$ Riccardo Rampini $^{1} \cdot$ Mikko Nikulainen $^{1}$
}

Published online: 15 July 2021

(c) CEAS 2021

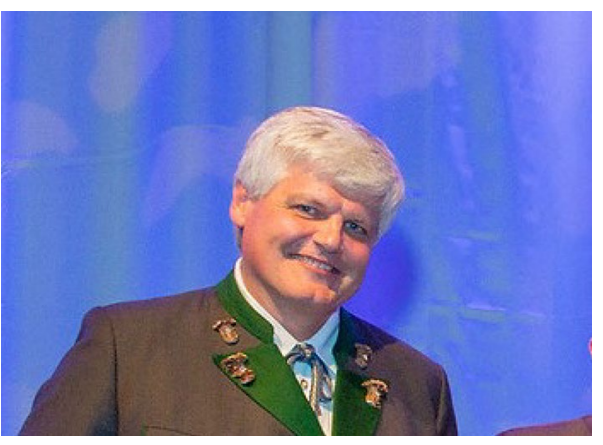

\section{Introduction}

Christopher was born in Leoben, Austria in 1968 and studied materials science at the Montan University, where he graduated with excellence in 1992. In his early academic career, Christopher studied ceramic matrix composites and crystallographic fractometry of fracture surfaces and he completed his dissertation on this topic at the Erich Schmid Institute for Materials Science in Austria.

Christopher joined the European Space Agency in 1998 as a materials engineer, and he was made Head of the

\section{This special edition is dedicated to the memory and legacy of our respected colleague Christopher Semprimoshnig, who sadly passed away in June 2020 at the age of 52. Christopher leaves behind his wife Carla, and two children Sophie and Lucas. The intention of this special issue is to showcase the general field of "Materials' Physics and Chemistry for Space Applications" which Christopher dedicated his career to, including the many diverse technical topics studied over the years together with his team within the European Space Agency, as well as with many international partners in academia, national space agencies, research institutes and industries.}

Ugo Lafont

ugo.lafont@esa.int

1 European Space Research and Technology Centre, European Space Agency, Keplerlaan 1, PO Box 299, 2200 AG Noordwijk, The Netherlands
Materials Physics and Chemistry Section in 2012. In early 2019, he was promoted to the Lead Engineer position within the Product Assurance and Safety Department. During his career in ESA, Christopher won several team achievement awards and he is owner of several patents. He also gave an annual summer course within the Department of Materials Science at his former university on the subject of Materials for Space Application.

After moving into the space business, Christopher continued to develop his expertise in materials science and engineering, especially focusing on the environmental durability of polymeric materials. He constructed numerous environmental test facilities for performing environmental exposure testing of materials and components, of which some notable examples were a synergistic radiation test facility, an atomic oxygen simulation facility, several UV test facilities, a hightemperature thermal vacuum oven and a facility for performing electrostatic discharge testing of materials (Fig. 1).

Coupled to these facilities, a number of innovative measurement devices for studying degradation effects were developed, including a spectrophotometer for performing thermo-optical measurements under vacuum and an in-situ temperature measurement system (Fig. 2).

Christopher utilized many different techniques to study degradation effects on materials. A particular interest was thermal analysis, and he utilized a number of advanced methods including coupled mass spectrometry \& thermogravimetric analysis. He also used model-free kinetics to predict the lifetime performance of adhesive systems. Indeed, accelerated testing and lifetime prediction was a common theme across much of his work and this remains a significant challenge today in the field of environmental testing.

It is of course difficult to make a complete list of the materials investigated, but there are some notable examples. During his career, he investigated all classes of materials (metals, polymers, ceramics and composites) from aerogel to film application. Metal bi-layers and interfaces with polymer 


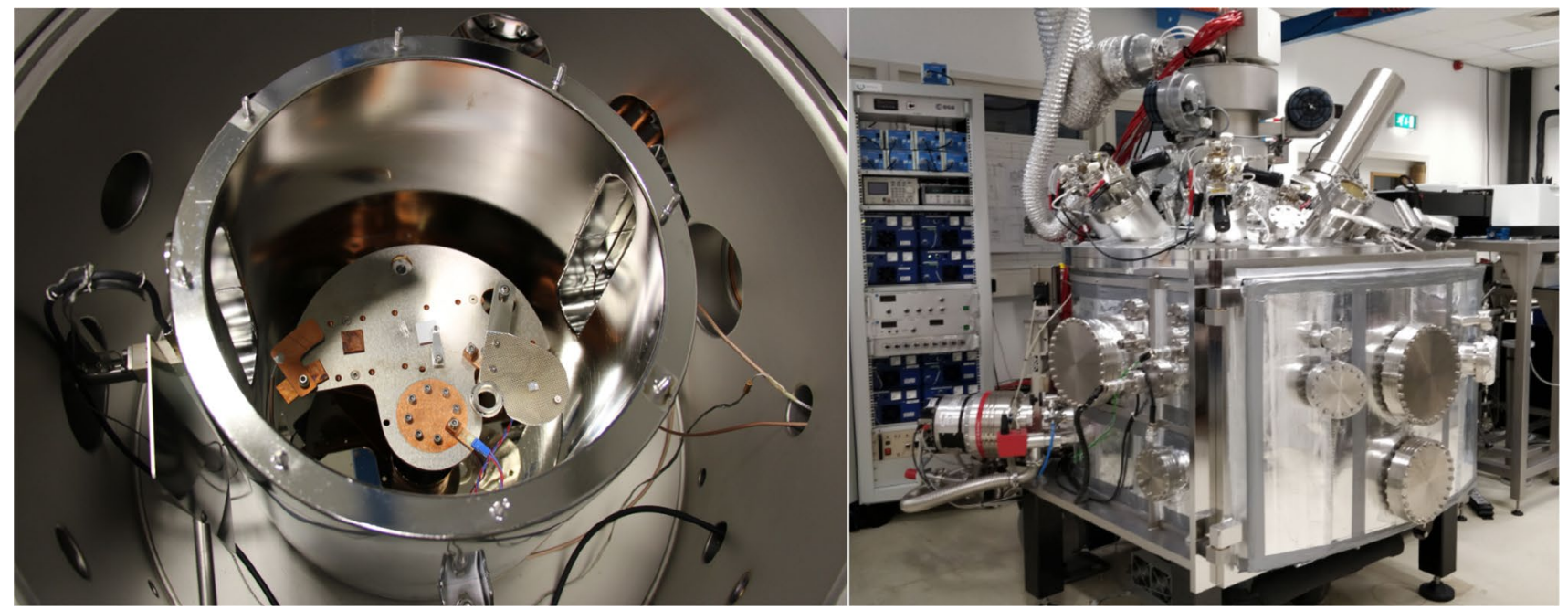

Fig. 1 ESTEC facilities: ESD chamber for materials charging studies (left) and the STARII facility for synergistic radiation testing and in-situ analysis (right)

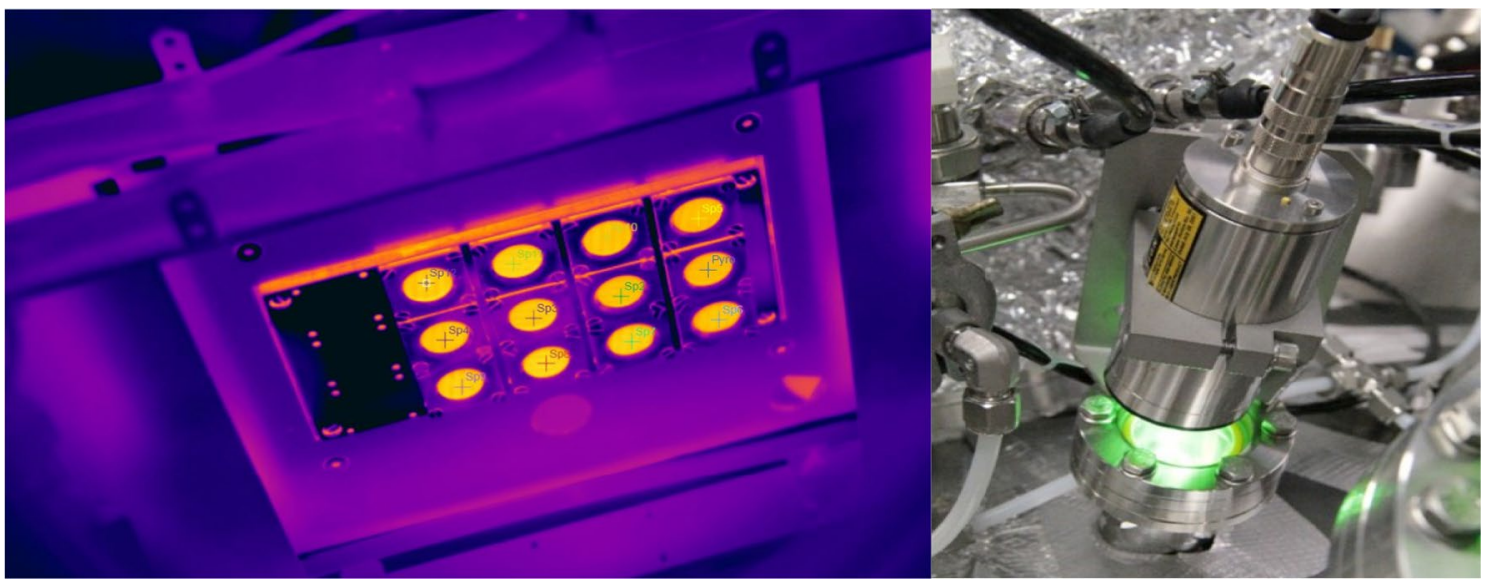

Fig. 2 In-situ temperature monitoring of samples during UV exposure testing. Sample plate is shown on the left and pyrometer measurement system is shown on the right

substrates were a recurring theme in Christopher's work, particularly the effects of extreme thermal cycling and radiation. Thermal control materials also feature prominently, including optical solar reflectors, solar cell materials, multilayer insulation and various types of thermal control coating.

\section{Materials}

Christopher performed a number of studies allowing the development of new materials for space application. Related to fiber-reinforced polymer (CFRP), in one study, carbon fiber/ PEEK composite was used to produce composite overwrapped pressure vessels (COPV) by mean of Laser-Assisted Tape-Placement including a full
PEEK-based liner. Such concept led to low permeability and enhanced damage resistance to crack formation under cryogenic application [1-3].

One of these was self-healing of composite structures, utilizing multi-component adhesive systems embedded in thin fibers. In 2005, he looked at self-healing material and concepts applied to composite structure for space application within Europe. The work performed demonstrated that autonomous healing concept implemented in composite structure via hollow fibers led to healing of damages and stay functional even after being exposed to vacuum and thermal cycling [4]. After this pioneering work, the self-healing concept was applied to PI film to enhance its resistance toward atomic oxygen erosion in Low Earth Orbit environment [5] and applied on COPV 
Fig. 3 (Left) ESA MELT 3D Printer and (Right) CubeSat body $3 \mathrm{D}$ printed using embedded electrically conductive PEEK (credit ESA)
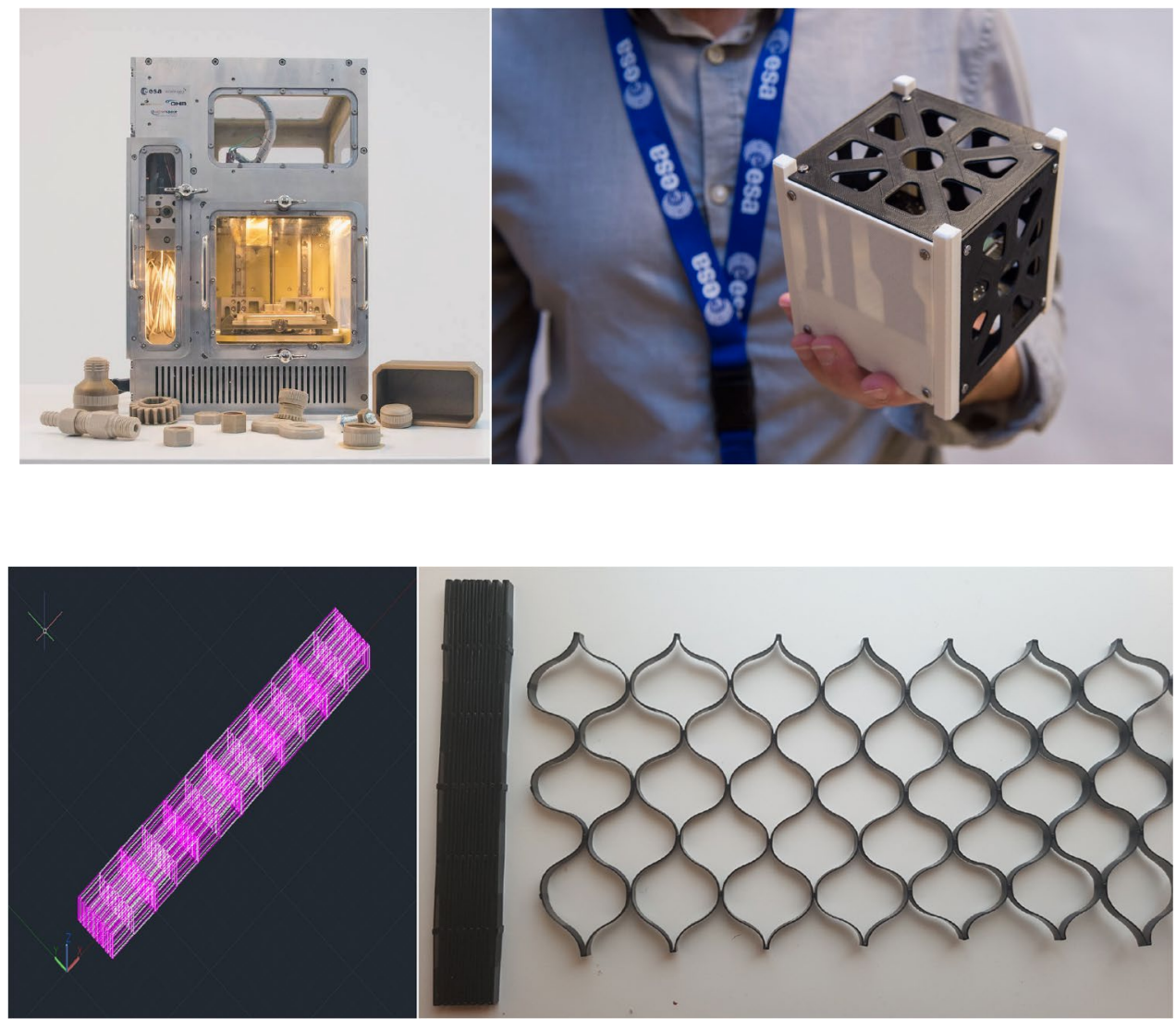

Fig. 4 (Left) 3D model of folded structure and (Right) printed folded structure before and after self-deployment by thermal stimulus

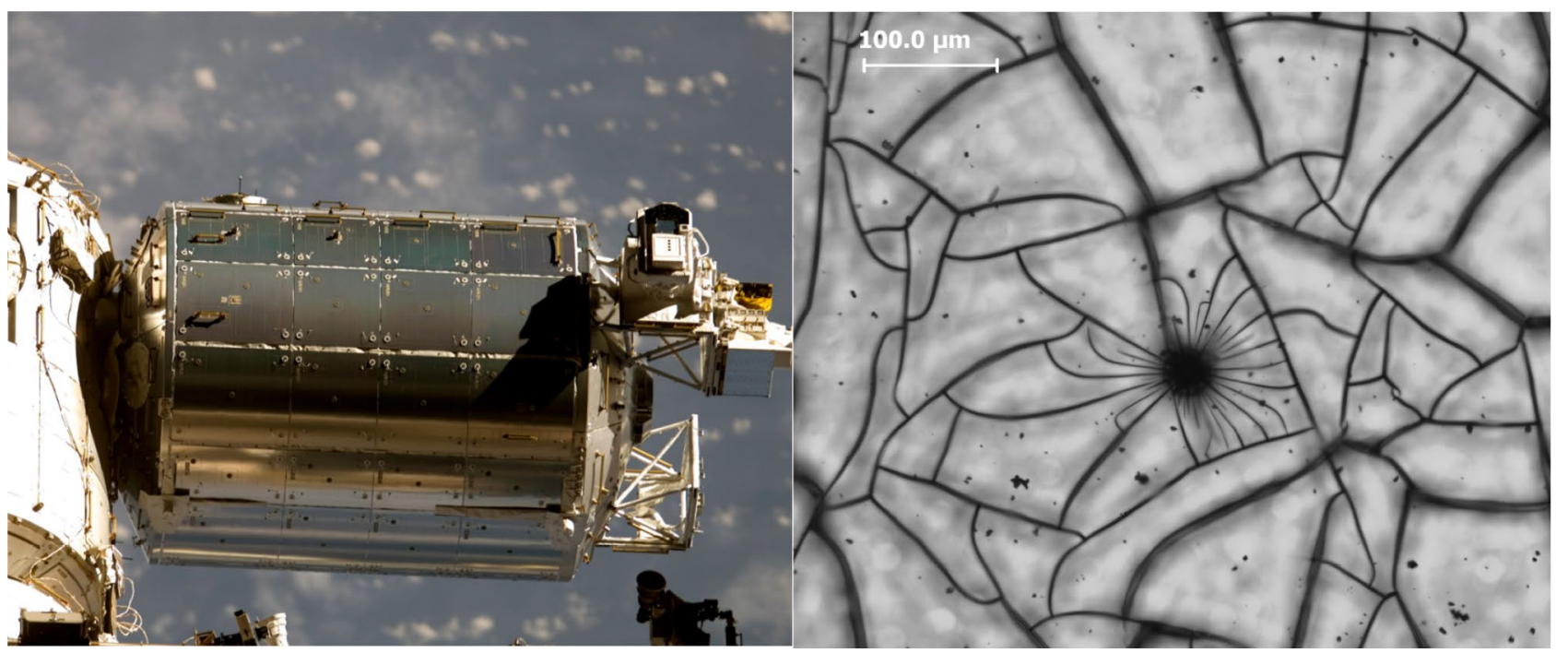

Fig. 5 MEDET flight experiment installed on ESA's Columbus laboratory on the International Space Station in 2010 (left) and space debris impact crater observed on one of the exposed MEDET samples during ground based analysis after retrieval (right)

using intrinsic healing materials for ballistic impact protection together with damage detection capabilities [6]. This baseline work performed is now pursued within ESA looking into self-healing concept for ballistic impact protection for inflatable structure.
Under Christopher's leadership, in 2015, ESA acquired the prototype of the first commercial 3D printer capable to print PolyEtherEtherKetone (PEEK) based on the Fused Filament Fabrication technology for its assessment for inspace manufacturing purpose [7]. Since then, this material 


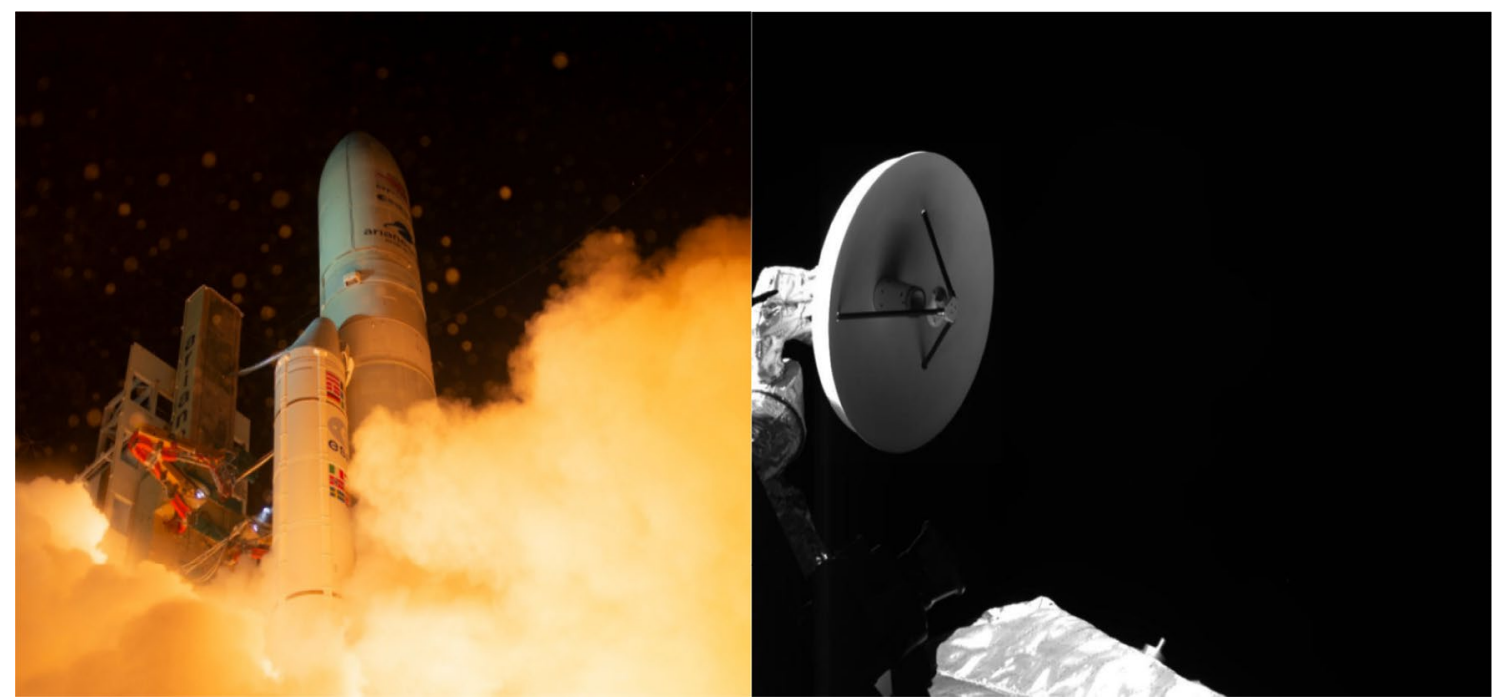

Fig. 6 Christopher witnessed the Bepi Colombo launch from Korou, French Guiana in October 2018 (left), after nearly two decades of working on the project. He helped to develop and test the white coat- ing for the high gain antenna, which can be seen nicely in this "space selfie" taken by the spacecraft's on-board monitoring camera as it continues its journey towards Mercury (right)

\section{Space environment}

oped worldwide for many on-ground applications. From a specific space application, his input led to the development of the ESA MELT printer (Fig. 3) suitable for operation in microgravity under the ISS operation constrain [8]. Other topics like the development of electrically conductive PEEK [9], PEEK recycling, looking into effect of vacuum during printing process [10] were conducted in his team. Finally, he contributed to better evaluate this specific material/process relationship in view of qualification and standardization for space application.

More recently, he started to look at additive manufacturing, going beyond 3D printing to assess 4D printing concepts for space application [11] using multi-material 3D printing technology. Mixing rigid and flexible polymers, it is possible to design and manufacture object with programmed residual strain that will lead to shape changing upon thermal stimulus (Fig. 4). At this time, the environmental exposure effects on the reversibility, durability and efficiency of such technology are being assessed.

Thermoelectric materials are very appealing for space application. Improvement of their efficiency has been one of Christopher's fields of investigation. He looked at the improvement of bulk properties of Chevrel phase-derived $\mathrm{Ag}_{3.6} \mathrm{Mo}_{9} \mathrm{Se}_{11}$ alloy by $\mathrm{Cu}$ insertion $\left(\mathrm{Ag}_{3.6} \mathrm{Cu}_{0.2} \mathrm{Mo}_{9} \mathrm{Se}_{11}\right.$ and $\mathrm{Ag}_{3.6} \mathrm{Cu}_{0.4} \mathrm{Mo}_{9} \mathrm{Se}_{11}$ ) [12], at optimize synthesis process for the enhancement of SnTe [13-15] and at SnSe single crystalline phase as promising new candidate for thermoelectric application [16].
Spaceflight experiments were of particular interest to Christopher, and he studied materials retrieved from the Long Duration Exposure Facility, the Hubble Space Telescope [17], as well as the Materials Exposure and Degradation Facility (MEDET) (Fig. 5) [18]. Very recently, he was involved in a new opportunity to expose new materials on the International Space Station. the understanding of the effect of the space environment on materials in general with a strong focus on thermo-optical properties [19]. Most of the materials used for thermal control were investigated: Polyimide [20], thin-polymer-film materials for potential use as solar sails [21], metal-polymerbased film [22-24].

Finally, the summary would not be complete without highlighting the specific space missions which Christopher contributed to. Notable examples are ESA's Venus Express [20, 25, 26], and the Bepi-Colombo mission to Mercury [27-30]. These missions created very specific challenges related to synergistic degradation of materials due to hightemperature and high-intensity UV exposure. Christopher led numerous investigations on the degradation properties of thermal control materials [31] and solar array materials [32] for these missions. A very notable contribution to the Bepi Colombo mission was the development and testing of a new high-temperature ceramic coating for the high gain antenna (Fig. 6) [33].
During his career, he dedicated a lot of effort to increase 


\section{Closing remarks}

This special issue gathers several original contributions related to the field of Materials' Physics and Chemistry for Space Application. We hope that this special journal edition can be used as a lasting reminder for Christopher's family of the work he performed, as well as a motivation for a future generation of young scientists and engineers working in this specialized field. Christopher's sudden passing at an early age is a great loss to the materials science and space community and his many friends and colleagues. We shall continue the work in his memory and continue to aim for scientific and engineering excellence, to quote a phrase which Christopher often used.

\section{References}

1. Murray, B.R., Leen, S.B., Semprimoschnig, C.O.A., Brádaigh, C.M.Ó.: Polymer lined COPVs formed using an integrally heated rotational moulding tool and laser assisted tape placement. In: International SAMPE Technical Conference (2016)

2. Murray, B.R., Doyle, A., Feerick, P.J., Semprimoschnig, C.O.A., Leen, S.B., Brádaigh, C.M.Ó.: Rotational moulding of PEEK polymer liners with carbon fibre/PEEK over tape-placement for space cryogenic fuel tanks. Mater. Des. 132, 567-581 (2017). https://doi.org/10.1016/j.matdes.2017.07.026

3. Murray, B.R., Leen, S.B., Semprimoschnig, C.O.A., Brádaigh, C.M.Ó.: Helium permeability of polymer materials as liners for composite overwrapped pressure vessels. J. Appl. Polym. Sci. (2016). https://doi.org/10.1002/app.43675

4. Trask, R.S., Bond, I.P., Semprimoschnig, C.O.A.: Self-healing of composite structures in a space ENVIRONMENT. In: European Space Agency, (Special Publication) ESA SP (2006)

5. Fischer, H.R., Semprimoschnig, C., Mooney, C., Rohr, T., Van Eck, E.R.H., Verkuijlen, M.H.W.: Degradation mechanism of silicone glues under UV irradiation and options for designing materials with increased stability. Polym. Degrad. Stab. 98, 720-726 (2013). https://doi.org/10.1016/j.polymdegradstab. 2012.12.022

6. Haddad, E., Zhao, Y., Celikin, M., Basti, M., Tagziria, K., Wallach, E., Semprimoschnig, C., Lafont, U., McKenzie, I.: Mitigating the effect of space small debris on COPV in space with fiber sensors monitoring and self-repairing materials. In: Proceedings of SPIE-The International Society for Optical Engineering (2018)

7. 3D printing in hard plastic. 2015. https://www.esa.int/ESA_Multi media/Videos/2015/10/3D_printing_in_hard_plastic

8. Daurskikh, A., Sgambati, A., Graça, D., Berg, M., Baptista, A., Angelo, M., Lafont, U.: Influence of spatial orientation on properties of 3D printed PEEK parts and their design adaptation. In: Proceedings of the international astronautical congress, IAC (2018)

9. Gonçalves, J., Lima, P., Krause, B., Pötschke, P., Lafont, U., Gomes, J., Abreu, C., Paiva, M., Covas, J., Gonçalves, J., Lima, P., Krause, B., Pötschke, P., Lafont, U., Gomes, J.R., Abreu, C.S., Paiva, M.C., Covas, J.A.: Electrically conductive polyetheretherketone nanocomposite filaments: from production to fused deposition modeling. Polymers (Basel) 10, 925 (2018). https://doi.org/ 10.3390/polym 10080925

10. Quinn, M., Guo, J., Lafont, U., Versteegh, J.: Fused filament fabrication of polycarbonate components in a simulated on-orbit environment. In: Proceedings of the international astronautical congress, IAC (2018)

11. Mitchell, A., Lafont, U., Hołyńska, M., Semprimoschnig, C.: Additive manufacturing - a review of 4D printing and future applications. Addit. Manuf. (2018). https://doi.org/10.1016/J. ADDMA.2018.10.038

12. Colin, M., Zhou, T., Lenoir, B., Dauscher, A., Al Orabi, R.A., Gougeon, P., Potel, M., Baranek, P., Semprimoschnig, C.: Optimization of bulk thermoelectrics: influence of $\mathrm{Cu}$ insertion in $\mathrm{Ag}$ 3.6Mo 9Se 11. J. Electron. Mater. 41, 1360-1364 (2012). https:// doi.org/10.1007/s11664-012-1906-Z

13. Ibrahim, D., Ohorodniichuk, V., Candolfi, C., Semprimoschnig, C., Dauscher, A., Lenoir, B.: Improved thermoelectric properties in melt-spun SnTe. ACS Omega 2, 7106-7111 (2017). https://doi. org/10.1021/acsomega.7b01397

14. Ibrahim, D., Candolfi, C., Migot, S., Ghanbaja, J., Dauscher, A., Le Caër, G., Malaman, B., Semprimoschnig, C., Lenoir, B.: Comprehensive study of the low-temperature transport properties of polycrystalline S $\mathrm{n} 1+\mathrm{xTe}(\mathrm{x}=0$ and 0.03 ). Rev. Mater Phys. (2019). https://doi.org/10.1103/PhysRevMaterials.3.085404

15. Ibrahim, D., Misra, S., Migot, S., Ghanbaja, J., Dauscher, A., Malaman, B., Semprimoschnig, C., Candolfi, C., Lenoir, B.: Transport properties of polycrystalline SnTe prepared by saturation annealing. RSC Adv. 10, 5996-6005 (2020). https://doi.org/ $10.1039 / \mathrm{c} 9 \mathrm{ra} 10841 \mathrm{f}$

16. Ibrahim, D., Vaney, J.-B., Sassi, S., Candolfi, C., Ohorodniichuk, V., Levinsky, P., Semprimoschnig, C., Dauscher, A., Lenoir, B.: Reinvestigation of the thermal properties of single-crystalline SnSe. Appl. Phys. Lett. (2017). https://doi.org/10.1063/1.4974348

17. Moser, M., Semprimoschnig, C.O.A., Van Eesbeek, M.R.J., Pippan, R.: Surface and bulk degradation of Teflon ${ }^{\circledR}$ FEP retrieved from the hubble space telescope solar arrays. High Perform. Polym. 20, 429-446 (2008). https://doi.org/10.1177/0954008308 089707

18. Fischer, H., Semprimoschnig, C.O.A.: Analysis of the durability of polymeric materials in space-application of scanning thermal microscopy. In: European Space Agency, (Special Publication) ESA SP (2006)

19. Hołyńska, M., Tighe, A., Semprimoschnig, C.: Coatings and thin films for spacecraft thermo-optical and related functional applications. Adv. Mater. Interfaces (2018). https://doi.org/10.1002/admi. 201701644

20. Heltzel, S., Semprimoschnig, C.O.A., Van Eesbeek, M.R.J.: Investigation of the degradation of thermal control materials by thermal analysis. High Perform. Polym. 20, 492-511 (2008). https://doi. org/10.1177/0954008308089713

21. Semprimoschnig, C.O.A., Gray, P.A., Nehls, M.K., Edwards, D.L.: Accelerated space environmental testing and analysis of ultra-thin polymer films for Gossamer space structures like solar sails. In: European Space Agency, (Special Publication) ESA SP (2006)

22. Putz, B., Wurster, S., Edwards, T.E.J., Völker, B., Milassin, G., Többens, D.M., Semprimoschnig, C.O.A., Cordill, M.J.: Mechanical and optical degradation of flexible optical solar reflectors during simulated low earth orbit thermal cycling. Acta Astronaut. 175, 277-289 (2020). https://doi.org/10.1016/j.actaastro.2020.05. 032

23. Putz, B., Milassin, G., Butenko, Y., Völker, B., Gammer, C., Semprimoschnig, C., Cordill, M.J.: Combined TEM and XPS studies of metal-polymer interfaces for space applications. Surf. Coat. Technol. 332, 368-375 (2017). https://doi.org/10.1016/j.surfcoat. 2017.07.079

24. Putz, B., May-Miller, C., Matl, V., Völker, B., Többens, D.M., Semprimoschnig, C., Cordill, M.J.: Two-stage cracking of metallic bi-layers on polymer substrates under tension. Scr. Mater. 145, 5-8 (2018). https://doi.org/10.1016/j.scriptamat.2017.09.039 
25. Heltzel, S., Semprimoschnig, C.O.A., Van Eesbeek, M.R.J.: Investigation of the degradation of thermal control materials by thermal analysis. In: European Space Agency, (Special Publication) ESA SP (2006)

26. Semprimoschnig, C.O.A., Heltzel, S., Eesbeek, M.R.J.V., Williamson, J.R., Tighe, A.P., Polsak, A.: The ESA venus express mission-from a materials engineering perspective. In: European Space Agency, (Special Publication) ESA SP (2006)

27. Moser, M., Ranzenberger, C., Varewijck, G., Lehmann, B., Ritter, H., Semprimoschnig, C., Battaglia, D., Bevilacqua, E., Schilke, J.: High temperature multilayer insulation of the bepicolombo spacecraft - a design at the edge of material capability. In: 40th international conference on environmental systems, ICES 2010 (2010)

28. Heltzel, S., Semprimoschnig, C.O.A., Van Eesbeek, M.R.J.: Environmental testing of thermal control materials at elevated temperature and high intensity UV radiation. In: European Space Agency, (Special Publication) ESA SP (2006)

29. Semprimoschnig, C.O.A., Heltzel, S., Polsak, A.: Materials behaviour at Mercury - challenges and first experimental results. In: International SAMPE Technical Conference. pp. 1259-1268 (2001)
30. Blair, S., Semprimoschnig, C., Van Casteren, J.: Hot stuff: seven steps in making a mission to Mercury. Eur. Sp. Agency Bull. 2011, 15-20 (2011)

31. Heltzel, S., Semprimoschnig, C.O.A., Van Eesbeek, M.R.J.: Environmental testing of thermal control materials at elevated temperature and intense ultraviolet radiation. J. Spacecr. Rockets. 46, 248-254 (2009). https://doi.org/10.2514/1.31892

32. Nömayr, C., Zimmermann, C., Janik, P., Semprimoschnig, C.: Degradation of solar array components in a combined UV/VUV high temperature test environment. In: E3S Web of Conferences (2017)

33. Holynska, M., Butenko, Y., Martins, R., Semprimoschnig, C., Meyer, F., Faber, S.: Studies of white ceramic coatings for ESA's bepicolombo mission to mercury. J. Spacecr. Rocket. 56, 13581370 (2019). https://doi.org/10.2514/1.A34230

Publisher's Note Springer Nature remains neutral with regard to jurisdictional claims in published maps and institutional affiliations. 